\title{
Time and Memory in The Cherry Orchard
}

\author{
Yueting Chen \\ Dongfang College, Zhejiang University of Finance \& Economics, 314408, China
}

\begin{abstract}
Characters are precisely aware of time in heterogeneous visions in Chekhov's last play The Cherry Orchard in 1904. This play has an obvious flow of time sense of nostalgia, realistic practical mind and eager thrust for the future manifesting in assorted roles. The industrious characters Dunyasha, Varya and Lopakhin check their watches regularly, presenting their alertness to time in the industrial age's. The older characters weep for their age and witness the weather's changes from May to October. Players value the same things in largely variant ways mostly according to the experience, age, class and gender ect.. Therefore, because of various personal aspirations, characters are living in their individual timelines as Lyubov's yearning for the past, Dunyasha, Yasha and Trofimoff's eager for the future, Firs' nostalgia and imprisonment at the present and Lopakhin's integrated past, current and future time view. Although characters have their particular time view, Chekhov in The Cherry Orchard embodies a prime time view that if the characters fail to come to terms with the nature of the flow of time, they would be living in fragmented visions and thus failed in fully experiencing the life.
\end{abstract}

Index Terms - time, memory, transition, Chekhov

\section{INTRODUCTION}

Characters are precisely aware of time in heterogeneous visions in Chekov's last play The Cherry Orchard in 1904. This play has an obvious flow of time sense of nostalgia, realistic practical mind and eager thrust for the future manifesting in assorted roles. The industrious characters Dunyasha, Varya and Lopakhin check their watches regularly, presenting their alertness to time in the industrial age's. The older characters weep for their age and witness the weather's changes from May to October. The various time vision could be analyzed in a quote of Francis Bacon (1893) on time:

for the truth is, that time seemeth to be of the nature of a river or stream, which carrieth down to us that which is light and blown up, and sinketh and drowneth that which is weighty and solid".

Players value the same things in largely variant ways mostly according to the experience, age, class and gender ect., however, they would have their personal "light" or "weighty" things to blown up or solidify at the different areas of the "river or stream". For instance, family members, quality of life and love are "weighty and solid" to the quondam landlord Lyubov; implementation of crossing classes to change the life of a peasant is the goal of Lopakhin; the old valet Firs merely wants to stay servants. Therefore, because of various personal aspirations, characters are living in their individual timelines as Lyubov's yearning for the past, Dunyasha, Yasha and Trofimoff's eager for the future, Firs' nostalgia and imprisonment at the present and Lopakhin's integrated past, current and future time view. Although characters have their particular time view, Chekhov in The Cherry Orchard embodies a prime time view that if the characters fail to come to terms with the nature of the flow of time, they would be living in fragmented visions and thus failed in fully experiencing their life.

\section{LYUBOV'S YEARNING FOR THE PAST}

Lyubov indulges in not only the past glorious cherry orchard but her childhood, her beloved dead husband and sevenyear-old son Grisha in the past time. Tait (2000) illustrates that many feminists recognize Lyubov's role is gendered because she shows lots of her emotion on her past and helping the others. She's willing to help the others since on one hand it could show her good heart, on the other hand, her existence would be mirrored by the identification of the others being financially helped. However, she is incapable to keep the wealth inherited from the ancestors because of her luxurious lifestyle. Moreover, she couldn't increase the value of the estate by a wise investment. She wallows in her sentimental affection even couldn't listen to Lopakhin's considerate plan to lease the cherry orchard as its good location for summer cottages to save the estate and bear the life expenses. She's a good woman to lend money to Pishtchik, take care of her lover in Paris and treat her servants as equal. Even she has an affection to her bookcase and table, which signifies the nature of materialism but her emotion to the history.

This play opens in the place of a nursery, with Lyubov's homecoming for the reason to refresh her life as mixed innocent, happy and bitter as in the childhood and grieved memories in the foregoing beautiful and flourishing cherry blossom. However, when she returns home there are straightforward financial problems and social changes but Lyubov still keeps her lifestyle on high expenses as if she's still on the first rank of society but without any incomes. Hence, it's no doubt she couldn't maintain her fleshpots hereafter. Her last property the cherry orchard ends by an auction only six months later after her returning. The new owner middle-aged Lopakhin is a businessman and he is the son of Lyubov's 
former peasant. His grandparents were slaves of the Ranevsky family before the country issues freedom to the serfs. Time watches the overturning social break of classes. After freeing of the serfs in Russia where progresses an unstable class revolution of Chekhov's day in the 19th century when The Emancipation Declaration was announced in 1861, which freed the serfs from being owned by landlords. Chekhov depicts the upheaval that the lower classes could enhance their status by diligent hardworking and the aristocrats collapse their positions with a laissez-faire recession by their effortless.

Lopakhin is a typical example presented in The Cherry Orchard, who cherishes every minute to change his destiny. He becomes richer and richer through his good commercial awareness while the Ranevsky family gradually lose their positional advantages by exhausting all their fortune. When he considers to pay back the kindness that Lyubov treats him in his teenage period, he warmly works out a plan to save the only home left of the Ranevskys:

As you already know, your cherry orchard is going to be sold off to pay your debts, the auction will be on August twenty-second, but don't worry, rest easy, there's a way out . . . Here's my plan. Please pay attention! Your estate is located only fifteen miles from town, the railroad now passes nearby, and if the cherry orchard and the land by the river were broken up into lots and leased out for building summer houses, you'd have an income of at least twenty-five thousand a year. (Chekhov, 2009, p. 51)

Lopakhin not only shows his wise business sense to protect the estate and increase its value and he expresses his gratitude with a good heart to Lyubov but also prudentially figures out the amount of earning from the cherry orchard by this strategy for his former owner although he doesn't really need to be their servant any longer. Nevertheless, the aristocratic family emotionally refuses the brilliant proposal. Gaev actually criticizes "Excuse me, but that's nonsense!" (Chekhov, 2009, p. 51) and Lyubov expresses her romanticism by incomprehension:

Chop it down? My dear, forgive me, but you understand nothing. If there's one thing in the whole province that's interesting, even remarkable, it's our cherry orchard. (Chekhov, 2009, p. 52)

Both Lyubov and her brother Gaev deny Lopakhin's suggestion. When Lopakhin explains the value of the cherry orchard is only the size, he anxiously asks Lyubov to earnestly consider the summer houses and if she makes a decision to keep the land as "Just one word! Give me an answer!" (Chekhov, 2009, p. 78), he would help her to get fifty thousand for the loan, however, the Ranevsky sister and brother simply show their indifference to Lopakhin's idea. In fact, this disagreement results from their different value systems. To Lyubov, her worthwhile things are past which become traumas at present so that keeping life going is not that important to her.

Alexander (2004) analyzes the external desperate event would manifest the internal traumatic response of an unconscious emotional fear and "psychological defense mechanism" model (p. 1-30). Based on his point of view, when comes tremendous harmful event, the victim will repress the traumatic experience to the unconscious area because of extreme astonishment and fear, thus becoming a psychological knot, which could be repressed, distorted and displaced in the actor's memory leading to irrational and irresponsible actions as hysteria. Apparently, when Lyubov encounters with this unbearable family disaster, her husband is unlovable and she says "to my misfortune I fell in love with another man" (Chekhov, 2009, p. 84), and after her son's death she feels guilty and leaves "without looking back" (Chekov, 2009, p. 45). She goes to France thinking of "never to return, never to see this river" (Chekov, 2009, p. 84). However, when her lover in Paris fleeced and abandoned her, she thinks to come back to Russia. Her experience of consistent trauma has always been curing by her self-defense mechanism of "transference" from a Freudian psychoanalysis theory. When she returns to the cherry orchard breaking her previous words, facing financial problem and the past trauma and hearing from the lover's begging for her forgiveness, she thinks going to Paris again. Nevertheless, her softheart, undiscerning and incapability cause her foreseeable gloomy future life. These problems ultimately are on the ground of her insouciant and inexperienced life living in the aristocratic family, far from the normal society. Her yearning for the past without learning useful living skills to deal with the difficulties in the real world presents Chekov's fair main discourse of supporting the new raising class who cherishes the time to show their diligence and wisdom to improve.

\section{FIRS’ ASPIRATION TO REMAIN THE DAYS AND HIS LIFELESSNESS}

Firs' aspiration to remain the days and his lifelessness ends with a self-sigh of meaningless existence. The age of this loyal old valet is 87 , which means he experiences his life for eighty seven years and definitely symbolizes the past himself. In the play, he wishes no change and no action and expects no future only to stay a servant as he says "If you please. (Joyfully) My lady has come home! How I’ve waited! Now I can die . . " (Chekov, 2009, p. 46). Firs doesn't like freedom:

(Laughs) When we got our freedom, I was already head valet. I didn't accept freedom then, I stayed with my masters . . I I remember everybody was glad, but what they were glad about they didn't know themselves. (Chekov, 2009, p. 88)

How could he know the others didn't know the reason they're happy for the freedom of serfs? But he has his personal different ideas that he believes freedom is a catastrophe indeed. When the Ranevskys are talking about nature, eternity, death, life and destroy, they hear a sound of a breaking string as if from the sky dying away sadly. Chekov here manifests his writing skill of impressionism that the sound of a breaking string implies the past serfdom as Firs 
mentions something would suggest a catastrophe such as "the owl screeched, and the samovar went on whistling" (Chekov, 2009, p. 95-96), he believes it is freedom. And this breaking string sound is echoed in the end of the play:

A distant sound, as if from the sky, the sound of a breaking string, dying away, sad. Silence ensues, and the only thing heard is an axe striking wood far off in the orchard. (Chekov, 2009, p. 284)

It shows it is not that simple as Chehov inkings at such an important place. However, the others don't treat Firs' words seriously. And though Chekhov doesn't clearly depict the death of the loyal old valet Firs, most probably he is dead as lying still on the floor since everyone forgets him even incautiously locks him in the house.

When Lyubov refuses Lopakhin's idea to chop the cherry orchard down to build summer houses and Gaev feels proud of their orchard being mentioned in the Encyclopedia for their nostalgic emotion, their loyal old valet Firs follows his master's opinion and recalls they made the cherry jam and sold dried cherries in Moscow and Kharkov forty or fifty years ago. But when Lyubov asks whether there someone could remember the way to dry the cherries, he replies people has forgotten that, which suggests although sometimes people may recall the past, they are forgetful. In fact, Lyubov carelessly asks for her curiosity but does not really care about how to run a business. When Firs returns to an empty and a dull stage, he and the governess Charlotta have an interesting talk about his female master Lyubov's forgetfulness. Firs says his mistress has lost her purse and the governess Charlotta replies that the mistress "constantly loses things. She's lost her life, too" (Chekov, 2009, p. 102). As a matter of fact, Lyubov is in a difficulty that she cares too much about the past and finally loses it.

In fact, people don't forget Firs at first, Anya questions for his situation for several times. She asks whether he has been sent to the hospital and Yasha, the young servant says: "I told them this morning. I suppose it's been done" (Chekov, 2009, p. 267). Anya dissatisfies his ambiguous answer and thus asks the clerk Epikhodov again to make sure his being in the hospital. Nonetheless, Epikhodov deems Firs, as a representative of the past, is living enough without necessary to see a doctor. At the same time, Yasha could dare to be "offended" by his female master _— "(Offended) I told Egor this morning. Why ask ten times!" (Chekov, 2009, p. 267), which indicates Yasha unconsciously accepts the benefits of freed serfs followed by The Emancipation Declaration in 1861. However, as an unhelpful and aggressive servant in a family, the masters haven't abandoned him and even will bring him together to Paris later. And when Varya asks again: "Has Firs been taken to the hospital?" (Chekov, 2009, p. 268) Anya imprudently affirms: "Yes, he has" (Chekov, 2009, p. 268). It shows her softheart, undiscerning and incapability as her mother. Lyubov seems to care Firs since when she's leaving, she says her first worry is the sick Firs. And this time Anya most certainly replies: "Firs has been sent to the hospital, mama. Yasha sent him this morning" (Chekov, 2009, p. 274). No matter they intentionally or unintentionally miss Firs, Firs is forgotten. As in the end of this play, Anya is excited and bids the house and the old life farewell to cheerfully expect the new life. Lyubov and Gaev had been waiting for remaining alone, hugging with each other and gingerly weeping. Lyubov clearly knows it's time to say goodbye to her dear, tender, and beautiful orchard, which definitely means making farewell to her life in the youth, and her happiness. Actually, she has the chance to keep the estate but she personally chooses another way to go since she no longer wants to remain the historical memory in mind, only new life could cure her trauma while the summer cottages could not. Trofimov also cheerfully expects new life. In the last scene when all people have gone and they lock all the doors, Firs appears with his usual dress "a jacket and white waistcoat, with slippers on his feet. He is ill" (Chekov, 2009, p. 284). Firs is forgotten, he still cares about the male master Gaev though. Obviously, the characters are both objective and subjective that some of them even contradictorily show their clear awareness to intentionally waste their lives (Borny, 2006). Firs is such an example. As the symbol of the past, unwilling to make any changes in his life, eventually he realizes his end of meaningless: "Life's gone by, as if I never lived" (Chekov, 2009, p. 284) and blames himself: "You've got no strength, you've got nothing left, nothing ... Eh, you . . blunderhead!" (Chekov, 2009, p. 284) Chekov conveys that changes are normal as "an axe striking wood" (Chekov, 2009, p. 266, 284) to "amidst the quiet" (Chekov, 2009, p. 284) in the timelines. Although it with "the sound of a breaking string" (Chekov, 2009, p. 223, 284) is "sounding solitary and sad" (Chekov, 2009, p. 284), the past is gone as the change in ownership of the lands "dying away, sad" (Chekov, 2009, p. 223, 284). Death is a destined part of life, which brings a new era.

\section{DAydREAms And MElancholy FOR the PASt AND PRESENT}

Daydreams of the characters such as Trofimov, Gaev, Dunyasha and Yasha comparing to Varya's melancholy for the past and present exemplify they have not cherish the full flow of life time and thus they live in fragmented visions and fail in fully experiencing their lives. Trofimov as an eternal student never graduated from university always gives his empty speech without any realistic actions. Lopakhin laughed at him for still going around with young ladies. Trofimov and the Ranevskys and Lopakhin talk about proud man and think there are nothing to be proud of since men are so vulnerable and majority of men are "coarse, ignorant and profoundly unhappy" (Chekov, 2009, p. 220). Trofimov asserts men must work but he doesn't really work himself. Chekov strongly accuses some of the hypocritical faces of the so-called intellectuals who think themselves holding a privileged power of knowledge but taking no practical actions through the mouth of Trofimov:

The vast majority of the intellectuals I know seek nothing, do nothing, and at the moment are unfit for work. They call themselves intellectuals, but they talk down to servants, treat peasants 
like animals, study poorly, read nothing serious, do precisely nothing, their science is only talk, and they have little understanding of art. They're all serious, they all have stern faces, they all talk only about important things, they philosophize, and meanwhile, in front of their eyes, workers eat disgusting food, sleep without pillows, thirty or forty to a room, with bedbugs everywhere, stench, dankness, moral filth . . . There's only dirt, banality, barbarism . . . Serious faces scare me; I don't like them. Serious conversations scare me. Better to be quiet. (Chekov, 2009, p. 221)

Trofimov himself is scolded too since he says "Better to be quiet" (Chekov, 2009, p. 192) but he always gives big empty speech as a "mangy mister" (Chekov, 2009, p. 192). Varya worries the intimate relationship between Anya and Trofimov but in fact they have the liberty to choose their love especially when Anya admires Trofimov indeed. Except Trofimov's empty talk, he really has some impressive ideas such as "All Russia is our orchard" (Chekov, 2009, p. 228) to warn people that Russia also faces the crisis of the same reasons why the Ranevskys loss their home. Moreover, lessons from the history should be taken in mind and people should atone for the past through suffering and tough grind (Chekov, 2009). Trofimov has hope for the future but he is too idealistic to be totally "free as the wind" (Chekov, 2009, p. 229). Trofimov can merely say: "the moon is rising" and "happiness comes, getting closer and closer" (Chekov, 2009, p. 230), which could only be believed by Anya. However, Trofimov observes the essence of the problem of the aristocrats when Lyubov worries her estate would be sold. He thinks no matter when it is sold, the glorious past time has gone and Lyubov should face to the reality, although she usually deceives herself by indulging in the past time, which causes her need of emotional attachment so that even a well-known playboy could utilize her (Chekov, 2009). In the meanwhile, Lyubov recognizes Trofimov's idleness and suggests him to finish his education. Nonetheless, they wouldn't listen to each other and insist on their own. Trofimov realizes building summer houses is a kind of fickleness as "waving your arms" (Chekov, 2009, p. 264), which signifies hedonism could not bring a flourishing prosperity in the long run. The old nobility having superficial perception of "sins" as Ranevsky states "We've sinned so very much ..." (Chekov, 2009, p. 212). In fact, the waving arms of their sins come from the "paradise" of one class being built upon the sweat and toil of another (Baehr, 1999, p. 102). He has some good qualities such as when Lopakhin tries to give some money to him for his traveling, he refuses because he holds himself aloof. As a matter of fact, daydreams of the characters manifest in their dialogue sometimes turning to monologue to "avoid their problems" (Deer, 1858, p. 34), which becomes an "essential expression of the central conflict" (Deer, 1858, p. 34). Thus, Chekov adopts an ambiguous writing on Trofimov's half mad and half intelligent words to deliver his critical time view of highbrow daydream.

In this play Chekov criticizes the unserviceability of knowledge. Although intellectuals are respected, if there is no practical use of the knowledge, except the eternal student, Epikhodov is another one to show Chekov's critical idea that knowledge is not the thing to be proud of but to use. It indirectly suggests to call on an industrial way to follow the industrial revolution of the raising Europe in his time _ Epikhodov says:

I'm a cultivated man, I read all sorts of learned books, but I simply cannot understand where things are heading, and what in fact I want, to go on living or to shoot myself, but in any case, as a matter of fact, I always carry a revolver with me. Here it is . . (Shows the revolver) (Chekov, 2009 , p. 204).

Epikhodov has no directions for the future, which indicates although he read books in the past but he gets the confusion to go ahead at the present. Namely, he is not able to experience the full flow of the time because of his out of actions to find out the routes. The educated governess Charlotta is disoriented to the future too. She says: "who I am, why I am, there's no knowing..." (Chekov, 2009, p. 204). Anya "dreamily" imagines her future life with mom to read lots of books together (Chekov, 2009, p. 271) but she never thinks about their poor economic situations and how to deal with that.

The landowner Pishchik dreams for getting payment from railroad across his land and his daughter Dashenka would have won lottery (Chekov, 2009, p. 188-189). Nonetheless, Pishchik has got the luck to have some Englishmen finding some sort of white clay in his soil (Chekov, 2009, p. 146), which signifies the value of the lands that even daydream sometimes could come true. However, making daydream is not praised by Chekov since the fulfillment isn't from his own effort, which could not last sooner or later.

Gaev is a lazy man who emotionally amuses himself in the past too. His daydreams are to have Anya marry a very rich man to help them to get rid of financial crisis, a rich aunt could give him a sum of roubles, or a fictional general may lend him the money on his signature, which show his laziness that just wants to sit idle and enjoy the fruits of others' work. He considers to arrange a loan to pay the interest of the land but never takes effective actions. He imprudently affirms the cherry orchard will not be sold by swearing on his honor, happiness and whole being (198) but unfortunately at last the estate is sold on the auction and he breaks his swear. His ridiculously ineffective solutions to their problem reflect the ludicrous self-deception that the Renevskys are guilty (Remaley, 1973). Gaev mentions he's a man of the eighties and he admits "it's a time that's not much praised" (Chekov, 2009, p. 199). Chekov particularly notices the time to show his ironical view towards Gaev since it is a time of reactionary and dark decade of economic stagnation in 1880s in Russia. Tsar Alexander II was assassinated by The People's Will in 1881 (Bushkovitch, 2012). After the death of Alexander II, Alexander III strengthens police rule to assume his autocratic monarchy to a peak. Therefore, 1880s becomes the darkest time of the feudal autocracy of Russian Tsar, which leads to a big recession of both ideology and economy (Bushkovitch, 2012). Gaev says the peasants love him (Chekov, 2009, p. 199) actually 
because of their inertia to treat the landowners good rather than he has a good heart not to torture them since he is incapable to run the business well.

Dunyasha and Yasha as a maid and a young servant prefer to imitate their masters' behaviors. Dunyasha learns the dress, hair up and sick trembling conduct but she hasn't been impacted the good sides of the aristocrats such as love and generosity. No wonder Lopakhin warns her to know her role (Chekov, 2009, p. 34). Dunyasha can't face her humble root past, thus she has an illusive present and being anxious to her future -

I've become anxious, I worry all the time. I was still a little girl when I was taken into the masters' household, I'm unused to the simple life now, and look how white my hands are, like a young lady's. I've become so pampered, I'm afraid of everything . . . It's scary. And if you deceive me, Yasha, I don't know what will happen to me. (Chekov, 2009, p. 206)

She learns the delusion of her masters but hasn't any practical survival skills in experiencing social life, no wonder she worries all the time. Even Charlotta's dog eats nuts and Pishchik hardly believes she could have such a luxurious living (Chekov, 2009, p. 38). However, these staff learn the prodigal habit from their bosses and the mistress connives with them. When Lyubov sold her only house near Menton, having very a few of money left, with her people eat in the station, she could order the most expensive foods and tip the waiter. Charlotta does so and Yasha, the young servant orders something as well. When Varya tells Yasha that his mother from the village has been waiting for seeing him for one day, he indifferently says: "As if I care" (Chekov, 2009, p. 194) and "Who needs her. She could have come tomorrow." (Chekov, 2009, p. 195) to show he really has not a kind and grateful heart. They just imitate the evil sides of the masters while forget the original innocent virtues. Yasha complains his country, people, boring surroundings, foods and his predecessor Firs and requests Lyubov to take him with her to Paris without showing any contributions (Chekov, 2009, p. 249). Peacockish Yasha could even manifest his capacity of discernment on champagne (Chekov, 2009, p. 261). Although it shows their fair harmonious getting along with each other, if there is no distinct between the masters and servants, why should Lyubov feed them since she faces a financial problem? These servants have nothing to help but heartlessly consume her to make the situation even more dangerous.

Another character Varya is thought looking like a nun as the same as before by Lyubov (Chekov, 2009, p. 166), which might be the main reason the vigorous Lopakhin hasn't proposed to her. They are quite different that when they talk to each other, they can't get the other's point such as the misunderstanding of the weather change (time change) (Chekov, 2009, p. 277). Varya has a very strong fatalism that she always expects God to help them (Chekov, 2009, p. 195, 198). Nevertheless, she has a sparking rational thinking mind that she knows Lopakhin wouldn't make proposal to her since he's getting rich and busy, showing no care for her while she is on a downhill path. She knows that her problem is short of money to be independent and she observes that's the problem to Lyubov's plight either. When the Ranevsky family face their only estate to be sold, she worries because they still hire musicians for dancing ball to have pleasure without enough money to pay (Chekov, 2009, p. 233). Varya scolds Epikhodov for his irresponsibility but only gets his disregard (Chekov, 2009, p. 252-53). These servants are more and more rebellious that the masters couldn't handle them easily. Consequently, servants become burdens to the masters. Although Varya gets her fatalism, because of her rationality to analyze the present issues, in the end of the play, she could exit "unhurriedly" (Chekov, 2009, p. 283).

\section{LOPAKHIN's INTEGRATED TIME VIEW}

Lopakhin is the only man in the play who holds an integrated time view of showing his gratitude and memory of the past, noticing the present time and having reasonable plan for the future. Therefore, he becomes the big winner to be the new owner of the cherry orchard since he is able to buy it in the auction. He remembers Lyubov's gentle treats and comforts to a poor boy when he was young.

I remember when I was a kid of about five or six, my late father-he kept a shop then, here in the village - punched me in the face with his fist. My nose bled ... We had come here to the yard together for some reason, and he was a bit drunk. Lyubov Andreevna, I remember it like today, still a young thing, so slender, she led me to the washstand, here, in this same room, in the nursery. "Don't cry, peasant-boy," she says, "it'll go away by your wedding day . . ." (Chekov, 2009, p. 162).

Only because of the warmth he feels from Lyubov, he tries at full split to help her to save the cherry orchard, although Lyubov and her brother respond indifferently and wouldn't listen to him. When Gaev revels in the past glorious time, laughing at Lopakhin as a "boor, a money-grubber" (Chekov, 2009, p. 179), Lopakhin says to him: "Yes, time flies" (Chekov, 2009, p. 176) to weaken the concern on the past time and watch the time flow by embracing the present time. He is anxious about the auction to sell Lyubov's cherry orchard and notices them many times to make up the minds to do something and reach a decision. However, they could casually change their attention from the serious topic to some recreational things. Lyubov even shows off eating crocodiles in Paris. Lopakhin is considerate to suggest that if Lyubov is loath to part with the beautiful scenery of the cherry orchard, she simply needs to wait for some time when the summer people begin to farm their little acres and then the cherry orchard will come back (Chekov, 2009, p. 183). He consistently reminds them "time is running out" (Chekov, 2009, p. 207) and is volunteer to deal with the case of keeping the estate because Lyubov took care of him with her goodness in the past time. Although the case might be 
tough to the others such as Lyubov and Gaev, to Lopakhin it's easy only that they give him a decision. In fact, thankful, rational and businesslike minds of Lopakhin are distinctly comparing to the features of "scatterbrained", "strange" and "unbusinesslike" (Chekov, 2009, p. 211) of the Ranevsky brothers, who present their privileged gesture and never give him a definite answer. Lyubov asks Lopakhin: "What are we to do? Teach us what to do" (Chekov, 2009, p. 211). It seems she is worrying likewise. Nonetheless, when Lopakhin affirmably tells them how to do, they won't agree with building summer houses as Lyubov says: "Summer houses, summer people-forgive me, but it's all so banal" (Chekov, 2009 , p. 211) to show her privileged taste. Chekov actually criticizes not only Lyubov as a short-sighted incapable woman who can't protect her estate but also Gaev who agrees with her, which evidences Chekov aims at their "wavingarms" (Chekov, 2009, p. 264) class problems. These unpractical previous landowners are frightened of the lands losing but they are unwilling to keep a low profile to sacrifice their daily high expenses which identify their status. They solely want to eat up "the whole fortune in fruit drops" (Chekov, 2009, p. 213) without any plans for the future. Lyubov could recognize her trouble that she tried to poison herself and she feels shameful but still doesn't want to change her hedonistic lifestyle, let alone could she earn money to develop. These former rich people currently just want effortless forgiveness and daydreaming of a bright future. They are also fragile that can't focus on handling difficulties for so long, when there is music, their attention is distracted (Chekov, 2009, p. 214) so that Lopakhin waits for their answer in vain.

Another example to show his honest memory to the past humble birth and rational mind to face the present situation is: although Lopakhin knows the differences between Trofimov and him, he remarkablely keeps his good essence of an earthy peasant and shows respect to the idealistic dream maker. Comparing to Trofimov, the symbol of academic knowledge, he says:

Oh, I'm rich all right, I've got lots of money, but if you really look into it, I'm as peasant as a peasant can be ... (Leafs through the book) I'm reading this book and don't understand a thing. I fell asleep reading it. (Chekov, 2009, p. 162)

Trofimov appreciates Lapakhin's vitality and pushfulness to the food chain and he knows the importance of realism but Trofimov himself plays his role as a theorist by boast. Moreover, Lopakhin modestly compensates his deficiencies by his diligence. He gets up at five in the morning, works from morning till night, and he could keep a good heart even fairly dealing with money that "few honest, decent people" (Chekov, 2009, p. 92) could have that composure. Earning money is not his only aim but to experience life by caring for the time when human beings get lots of materials from the nature: "Lord, you gave us vast forests, boundless fields, the deepest horizons, and we who live here should be real giants ourselves ..." (Chekov, 2009, p. 222). Although Lyubov has different understanding of the giants to Lopakhin's when she expresses her view that giants "are only good in fairy tales, otherwise they're frightening" (Chekov, 2009, p. 222), Lopakhin is appraised by Chekov for his realistic attitude to find the dignity.

He has a soft heart but a rational analyzing mind further, which are beneficial to plan for the future. Savely researches on Chekov's letter to his friend Stanislavsky that he wrote:

When I was writing Lopakhin, I thought it was your role . . Lopakhin, true, is a merchant, but he is a decent man in all regards; he must act in a dignified manner, as an educated person, without trifling or tricks, and thus I was thinking that this role, central in the play, would be a success by you. (Chekov, 2009, p. 13)

Genuinely, Chekov portrays Lopakhin a notably positive image. When a passerby requires for Lyubov's money, Lopakhin criticizes: “(Angrily to himself) For every outrage, there's decency!” (Chekov, 2009, p. 225) while Lyubov still plays her Maria role to give the passerby a gold piece. It presents Lopakhin's evaluate talent that he knows who is worth helping and who is to be denied. He could accelerate fortune as well. On the contrary, Lyubov only knows to consume her fortune regardless of her capacity and even asks Lopakhin to lend some money to her. Lopakhin generously agrees with her. But there is a decency to help the Ranevsky family. When he feels disappointed with these "scatterbrained people" (Chekov, 2009, p. 211), he buys the cherry orchard for a profitable business himself excitedly: "I'm dreaming, I'm making it up, it only seems so . . " (Chekov, 2009, p. 257). Lopakhin unhesitatingly takes "the axe to the cherry orchard", watching "the trees fall down!" to fulfill his plan to build summer houses to make a new life there (Chekov, 2009, p. 258). However, Deer identifies Lopakhin scolds himself to be higher than his previous class as he humbly notes he's a peasant, no matter how rich he could become (Chekov, 2009, p. 32). Although he has not been well-educated at school, he takes lessons in the real world. His ability brings him more liberty to be himself. He gets a good sense of knowing people that he reasonably hasn't chosen Varya as his life partner to satisfy the others' expectation because they really can't understand each other. Therefore, because of his integrated time view to cherish the past and present time and rationally plan for the future can he fully experience his life.

\section{CONCLUSION}

Characters in the play think a lot about the present comparing to the past since The Cherry Orchard sets the plot in a historical time with the overturn of the social classes. The Cherry Orchard witnesses the past of the Russian empire, evoking an emotion of longing, regret, or disgust - sometimes a combination of all three. Most characters wish to save the estate but in the end of the play the symbol of the past is snipped. The estate is sold, the masters are leaving and the old servant dies to enter into a new era. The Emancipation Declaration in 1861 of Alexander II undoubtedly is an essential policy in the time, which causes to a class instability. Chekhov portrays the picture of mixed-up Russia after 
freeing of the serfs. There are servants who regard freedom as a catastrophe, like 87-year-old Firs. There are servants who imitate ladies and gentlemen, such as Dunyasha and Yasha. Some characters are daydreaming such as the eternal student Trofimov and the landowner Pishchik. Some former peasants are getting richer and richer like Lopakhin. Most importantly, the previous rich landowners are on the recessional way.

Chekhov in The Cherry Orchard manifests the main discourse that a model in the play Lopakhin who nourishes the whole time periods succeeds in fully experiencing a realistic life because he fairly learns from the past, faces to the present and plans for the future. Although time is just a period of eternity, these characters construct an impressive memory of the historical Russia in the late 19th century and the early of 20th century. Reid (2005) deems Chekov's writing is influenced by Gorky's eschatological (political) strivings which continuously voices other perspectives. Many voices has been popped out in the unstable society as Bakhtinian "heteroglossia" (xix) but the main discourse at that time is to support the raising classes like Lopakhin to change the serfdom to an industrial society by their diligence and initiative to enhance the economic situation and social status. It concludes "weighty" things such as Lyubov's love (abused though) and Lopakhin's courage, wisdom and diligence on the raising middle-class solidify in a stream of the time to become a memorable episode of eternity in the work of Chekov's The Cherry Orchard.

\section{REFERENCES}

[1] Alexander, Jeffery C. et. al. (2004). Cultural Trauma and Collective Identity. Berkeley: University of California Press, 1-30.

[2] Bacon, Francis. (1893). The Advancement of Learning. Project Guttenberg, www.gutenberg.org/files/14264/14264-h/14264h.htm (accessed 20/2/2019).

[3] Baehr, Stephen L. (1999). The Machine in Chekhov's Garden: Progress and Pastoral in The Cherry Orchard. The Slavic and East European Journal, Vol. 43, No. 1 (Spring, 1999), 99-121.

[4] Bakhtin, M M, and Michael Holquist. (1981). The Dialogic Imagination: Four Essays. Austin: University of Texas Press.

[5] Borny, Geoffrey. (2006). The Cherry Orchard: Complete Synthesis of Vision and Form. Interpreting Chekhov. Canberra: ANU Press.

[6] Bushkovitch, Paul. (2012). A Concise History of Russia. New York: Cambridge UP.

[7] Chekhov, Anton. (2009). The Cherry Orchard. Trans. Richard Nelson et al. London: Faber.

[8] Deer, Irving. (1958). Speech as Action in Chekhov's The Cherry Orchard. Educational Theatre Journal, Vol. 10, No. 1, $30-34$.

[9] "Plot analysis of The Cherry Orchard." (2017). Shmoop Premium. http://www.shmoop.com/cherry-orchard/plot-analysis.html (accessed 19/3/2017).

[10] Reid, John McKellor. (2005). Polemic as Parting Advice: The 'Argument' of The Cherry Orchard. Modern Drama Vol. 48, No. 1, 30-54.

[11] Remaley, Peter P. (1973). Chekov's The Cherry Orchard. South Atlantic Bulletin, Vol. 38, No. 4, 16-20.

[12] Senderovich, Savely. (1994). The Cherry Orchard: Chekhov's Last Testament. Russian Literature, Volume 35, $223-242$.

[13] Tait, Peta. (2000). Performative Acts of Gendered Emotions and Bodies in Chekhov's The Cherry Orchard. Modern Drama Vol. 43, No. 1, 87-99.

Yueting Chen was born in Tongren, China in 1985. She is a PhD student of British and American Literature in her 4th year in National Chengchi University, Taiwan.

She is currently a lecturer in the School of Foreign Languages, Zhejiang University of Finance \& Economics Dongfang College, Haining, China. Her research interests include modern and contemporary literature. 